\title{
Retrospective study of plasma exchange in patients with idiopathic rapidly progressive glomerulonephritis and vasculitis
}

\author{
A Gianviti, R S Trompeter, T M Barratt, M F Lythgoe, M J Dillon
}

\begin{abstract}
A retrospective study of 48 patients was conducted to evaluate the efficacy of plasma exchange in children with idiopathic rapidly progressive glomerulonephritis (IRPGN), and renal or non-renal vasculitis. All patients were followed up at a single centre over a 15 year period. Treatment consisted of corticosteroids and/or cytotoxic agents. Plasma exchange was used in all patients because of severe renal involvement and/or clinical deterioration. One hundred per cent of patients with renal vasculitis who started plasma exchange within one month of disease onset and $58 \%$ of cases with IRPGN had significant improvement in renal function. No relapses of vasculitis were observed after treatment with plasma exchange in patients with renal and nonrenal vasculitis. The results suggest that plasma exchange associated with immunosuppressive treatment could be of benefit in cases of IRPGN or vasculitis in terms of both renal and extrarenal recovery.

(Arch Dis Child 1996;75:186-190)
\end{abstract}

Keywords: rapidly progressive glomerulonephritis, plasma exchange, systemic lupus erythematosus, vasculitis, Henoch-Schönlein purpura.

There is evidence that plasma exchange treatment may be effective in autoimmune diseases with documented circulating antibodies and/or immune complexes. ${ }^{1-3}$ The majority of the reports in the literature concern the use of plasma exchange in adult patients with vasculitis and idiopathic rapidly progressive glomerulonephritis (IRPGN). ${ }^{2-11}$ Although some prospective trials have been conducted, ${ }^{568-11}$ authors have not always agreed on the efficacy of plasma exchange. Data available on children are scanty; only a few cases have been reported in the last 10 years, ${ }^{12-16}$ and no prospective trials have been performed.

The aim of this study was to evaluate retrospectively the outcome of children with IRPGN or severe vasculitis after plasma exchange treatment.

Correspondence to: Dr Alessandra Gianviti, Divisione di Nefrologia e Dialisi, Ospedale Pediatrico Bambino Gesù, Piazza Sant' Onofrio 4, 00165 Roma, Italy.

Accepted 3 April 1996
Subjects

The children presented at the Hospital for Sick Children, Great Ormond Street, London from
1979-93. IRPGN was considered to be present in patients with impaired renal function, evidence of crescents $\geqslant 50 \%$ on renal biopsy, and no obvious cause nor clinical or serological evidence of non-renal disease. For purposes of analysis, vasculitis was considered to include Henoch-Schönlein purpura, polyarteritis nodosa, Wegener's granulomatosis as well as systemic lupus erythematosus, and was defined according to the criteria developed by the American College of Rheumatology. ${ }^{17-20}$ Forty eight patients treated with plasma exchange were reviewed: 25 boys and 23 girls. Mean (SD) age at the onset of disease was 8.5 (3.4) years (range 1.4-15.9). There were 12 cases of IRPGN, 17 of Henoch-Schönlein purpura, 11 of polyarteritis nodosa (two microscopic and nine macroscopic), six of systemic lupus erythematosus, and two of Wegener's granulomatosis. Table 1 shows the clinical features at onset. Of the 36 patients with vasculitis, 21 (58\%) presented with RPGN. Erythrocyte sedimentation rate (ESR) was used as a gauge of disease activity in patients with polyarteritis nodosa, systemic lupus erythematosus, and Wegener's granulomatosis. In these cases, the mean value at onset was $63 \mathrm{~mm} /$ hour (range 38-80).

The time between the onset of the disease and the start of plasma exchange (time of onset-plasma exchange) was reviewed in all patients to determine any difference between patients who improved and patients who did not improve.

\section{CLINICAL FEATURES THAT LED TO PLASMA}

EXCHANGE

For the purpose of this study, the patients were divided into three different groups depending on their main clinical and laboratory manifestations at the start of plasma exchange. Group A: IRPGN; 12 cases (table 2); plasma exchange was used because of severe renal involvement; the mean (SD) time of onsetplasma exchange was 1.3 (1.3) months (range 4 days -5 months). Group B: RPGN and vasculitis; 21 cases (table 3 ); 15 cases were treated with plasma exchange because of renal disease and clinical severity at onset (mean (SD) time of onset-plasma exchange: 1.0 (0.48) month; range 6 days-2 months), whereas six cases were started on plasma exchange when renal function deteriorated despite immunosuppressive medication (mean (SD) time of onset-plasma exchange: 31.0 
Table 1 Clinical features at presentation

\begin{tabular}{|c|c|}
\hline & $\begin{array}{l}\text { No of } \\
\text { patients }\end{array}$ \\
\hline \multicolumn{2}{|l|}{$\operatorname{IRPGN}(n=12)$} \\
\hline Acute renal failure & 12 \\
\hline Hypertension & 10 \\
\hline \multicolumn{2}{|l|}{ Henoch-Schönlein purpura $(n=17)$} \\
\hline Purpura & 17 \\
\hline Bowel involvement & 13 \\
\hline Renal involvement & 14 \\
\hline Neurological involvement & 3 \\
\hline \multicolumn{2}{|l|}{ Systemic lupus erythematosus ( $n=6$ ) } \\
\hline Malar rash & 3 \\
\hline Arthritis & 3 \\
\hline Renal involvement & 4 \\
\hline Lung involvement & 2 \\
\hline Epistaxis & 1 \\
\hline Neurological involvement & 1 \\
\hline Haematological disorder & 4 \\
\hline ANA positivity & 5 \\
\hline Anti-DNA positivity & 5 \\
\hline Anticardiolipin antibodies & 1 \\
\hline \multicolumn{2}{|l|}{ Polyarteritis nodosa $(n=11)$} \\
\hline Weight loss & 7 \\
\hline Rash & 6 \\
\hline Livedo reticularis & 1 \\
\hline Testicular pain & 1 \\
\hline Myalgias, weakness & 7 \\
\hline Neuropathy & 1 \\
\hline Hypertension & 3 \\
\hline Renal involvement & 2 \\
\hline Angiographic abnormalities & $8 / 8$ \\
\hline Aneurysms & 7 \\
\hline Occlusions & 3 \\
\hline Kidneys & 8 \\
\hline Liver & 5 \\
\hline Brain & 1 \\
\hline $\begin{array}{l}\text { Periarteriolar neutrophil infiltrate on muscle } \\
\text { biopsy }\end{array}$ & 1 \\
\hline Lung involvement & 2 \\
\hline Haemoptysis & 1 \\
\hline Epistaxis & 2 \\
\hline Asthma & 2 \\
\hline Neurological involvement & $\cdot 3$ \\
\hline Uveitis & 1 \\
\hline \multicolumn{2}{|l|}{ Wegener's granulomatosis $(n=2)$} \\
\hline Epistaxis & 2 \\
\hline Renal involvement & 1 \\
\hline Granulomatous inflammation on nasal biopsy & 1 \\
\hline Uveitis & 1 \\
\hline
\end{tabular}

ANA = antinuclear antibody.

(35.6) months; range 4-96 months) (table 3, numbers $1,2,10,12,18,19)$. Two of the 21 patients also had a cerebral disease. Group C: vasculitis without renal disease; 15 cases (table 4): five with cerebral symptoms, nine cases manifested severe deterioration or features of clinical activity (flare-up), and one with systemic lupus erythematosus had thrombocytopenia resistant to immunosuppressive medication. The mean (SD) time of onsetplasma exchange was 2.3 (1.9) months (range 10 days -5 months) in nine cases, and 29.0 (28.3) months (range 9-84) in six cases. These six patients initially responded to immunosuppressive medication, but later they also started plasma exchange because of disease flare-up with severe general deterioration.

\section{HISTOLOGY}

Percutaneous renal biopsy was performed in 33 cases, all with renal involvement. The most common glomerular lesion was endocapillary crescentic proliferation in 28 patients (85\%). Ten of the 12 cases with IRPGN presented $100 \%$ crescents, while the other two presented $75 \%$ and $90 \%$ crescents. Twelve of 14 patients with Henoch-Schönlein purpura showed 30\%$100 \%$ crescents, whereas two cases had diffuse proliferation without crescents.

Of four cases with systemic lupus erythematosus, two had $40 \%-50 \%$ crescents, and two diffuse proliferation without crescents. One patient with polyarteritis nodosa had $100 \%$ crescents and one showed ischaemic features consistent with this diagnosis. The patient with Wegener's granulomatosis showed $100 \%$ crescents.

\section{IMMUNOSUPPRESSIVE MEDICATION}

The patients were treated with immunosuppressive medication. The dosage was the same in each disease. All patients in group A received oral prednisolone $(2 \mathrm{mg} / \mathrm{kg} /$ day $), 11$ also received oral cyclophosphamide (2-3 $\mathrm{mg} / \mathrm{kg} /$ day), and four azathioprine. In group $B$, nine patients were given methylprednisolone intravenously (15-20 mg/kg/day) for 3-4 consecutive days; all patients received prednisolone; 17 received oral cyclophosphamide and 13 azathioprine, which was given when cyclophosphamide was discontinued in 12 patients. The patient with Wegener's granulomatosis was switched to cyclosporin (5-6 mg/ $\mathrm{kg}$ /day) after treatment with cyclophosphamide and azathioprine. Nineteen patients (10 in group $A$ and nine in group B) required dialysis at the onset of the disease. In croup $C$, six cases received methylprednisolone intravenously; all patients received oral prednisolone; 10 were given oral cyclophosphamide and eight also azathioprine when cyclophosphamide was discontinued; four patients were switched to cyclosporin after treatment with cyclophosphamide and azathioprine. Eleven cases are still on low dosage of immunosuppressive medication (one with HenochSchönlein purpura, three systemic lupus ery-

Table 2 IRPGN

\begin{tabular}{|c|c|c|c|c|c|c|c|c|c|}
\hline \multirow[b]{2}{*}{$\begin{array}{l}\text { Patient } \\
\text { No }\end{array}$} & \multirow[b]{2}{*}{ Sex } & \multirow[b]{2}{*}{$\begin{array}{l}\text { Age at } \\
\text { onset } \\
\text { (years) }\end{array}$} & \multicolumn{2}{|c|}{ Before plasma exchange } & \multirow[b]{2}{*}{$\begin{array}{l}\text { Renal biopsy } \\
\text { (\% crescents) }\end{array}$} & \multirow[b]{2}{*}{$\begin{array}{l}\text { Time onset-plasma } \\
\text { exchange (months) }\end{array}$} & \multirow[b]{2}{*}{$\begin{array}{l}\text { Serum creatinine } 2 \text { months } \\
\text { after plasma exchange } \\
(\mu \mathrm{mol} / \mathrm{l})\end{array}$} & \multicolumn{2}{|c|}{ Last follow up } \\
\hline & & & $\begin{array}{l}\text { Serum creatinine } \\
(\mu \mathrm{mol} / \mathrm{l})\end{array}$ & Dialysis & & & & $\begin{array}{l}\text { Time } \\
\text { (years) }\end{array}$ & Outcome \\
\hline 1 & $\mathbf{F}$ & 6.6 & 547 & ++ & 100 & 0 & 70 & 8 & Creatinine $75 \mu \mathrm{mol} / 1$ \\
\hline 2 & $\mathbf{M}$ & 11.3 & 700 & ++ & 100 & 0 & 61 & 4 & Creatinine67 $\mu \mathrm{mol} / 1$ \\
\hline 3 & $\mathbf{M}$ & 3.8 & 433 & ++ & 90 & 1 & 400 & 7 & ESRF \\
\hline 4 & $\mathbf{F}$ & 12.5 & 1566 & ++ & 100 & 2 & 800 & - & Death \\
\hline 5 & $\mathbf{F}$ & 10.1 & 524 & ++ & 100 & 2 & 500 & 4 & ESRF \\
\hline 6 & $\mathbf{M}$ & 8.5 & 220 & - & 100 & 0 & 66 & 3 & Creatinine $62 \mu \mathrm{mol} / 1$ \\
\hline 7 & $\mathbf{M}$ & 9.4 & 615 & - & 75 & 1 & 69 & 2 & Creatinine $46 \mu \mathrm{mol} / 1$ \\
\hline 8 & $\mathbf{M}$ & 7.0 & 750 & ++ & 100 & 1 & 90 & 1.6 & Creatinine $58 \mu \mathrm{mol} / 1$ \\
\hline 9 & $\mathbf{F}$ & 6.1 & 414 & ++ & 100 & 1 & 400 & 1 & ESRF \\
\hline 10 & $\mathbf{M}$ & 2.1 & 300 & ++ & 100 & 0 & 27 & 1 & Creatinine $36 \mu \mathrm{mol} / 1$ \\
\hline 11 & $\mathrm{~F}$ & 13.0 & 1088 & ++ & 100 & 5 & 800 & 1 & ESRF \\
\hline 12 & $\vec{M}$ & 11.0 & 960 & ++ & 100 & 1 & 170 & 1 & ESRF \\
\hline
\end{tabular}


Table $3 \quad R P G N$ and vasculitis $(n=21)$

\begin{tabular}{|c|c|c|c|c|c|c|c|c|c|c|}
\hline \multirow[b]{2}{*}{$\begin{array}{l}\text { Patient } \\
\text { No }\end{array}$} & \multirow[b]{2}{*}{ Sex } & \multirow[b]{2}{*}{$\begin{array}{l}\text { Age at } \\
\text { onset } \\
\text { (years) }\end{array}$} & \multicolumn{2}{|c|}{ Before plasma exchange } & \multirow[b]{2}{*}{$\begin{array}{l}\text { Renal biopsy } \\
\text { (\% crescents) }\end{array}$} & \multirow[b]{2}{*}{$\begin{array}{l}\text { Time onset-plasma } \\
\text { exchange (months) }\end{array}$} & \multirow[b]{2}{*}{$\begin{array}{l}\text { Serum creatinine } 2 \text { months } \\
\text { after plasma exchange } \\
\text { ( } \mu \text { molll) }\end{array}$} & \multicolumn{3}{|c|}{ Last follow up } \\
\hline & & & $\begin{array}{l}\text { Serum creatinine } \\
(\mu \mathrm{mol} / \mathrm{l})\end{array}$ & Dialysis & & & & $\begin{array}{l}\text { Time } \\
\text { (years) }\end{array}$ & Outcome & \\
\hline \multicolumn{11}{|c|}{ Henoch-Schönlein purpura } \\
\hline 1 & F & 6.4 & 110 & - & 60 & 9 & 47 & 2 & ESRF & \\
\hline 2 & M & 9.0 & 200 & - & 60 & 4 & 88 & 1 & ESRF & \\
\hline 3 & $\mathbf{M}$ & 11.9 & 86 & - & 80 & 1 & 60 & 6 & Creatinine & $80 \mu \mathrm{mol} / 1$ \\
\hline 4 & $\mathrm{~F}$ & 9.5 & 490 & - & 100 & 0 & 120 & 6 & Creatinine & $170 \mu \mathrm{mol} / 1$ \\
\hline 5 & $\mathbf{M}$ & 8.0 & 710 & ++ & 80 & 1 & 120 & 1 & Creatinine & $76 \mu \mathrm{mol} / 1$ \\
\hline 6 & $\mathbf{M}$ & 5.1 & 330 & ++ & DEP & 0 & 58 & 4 & Creatinine & $58 \mu \mathrm{mol} / 1$ \\
\hline 7 & $\mathbf{M}$ & 10.0 & 790 & ++ & DEP & 1 & 62 & 3 & Creatinine & $53 \mu \mathrm{mol} / 1$ \\
\hline 8 & $\mathbf{M}$ & 8.9 & 112 & - & 50 & 1 & 41 & 2 & Creatinine & $60 \mu \mathrm{mol} / 1$ \\
\hline 9 & $\mathrm{~F}$ & 11.5 & 300 & - & 88 & 1 & 87 & 2 & Creatinine & $58 \mu \mathrm{mol} / 1$ \\
\hline 10 & $\mathbf{M}$ & 3.7 & 124 & - & 30 & 48 & 120 & 7 & ESRF & \\
\hline 11 & $\mathbf{M}$ & 5.6 & 230 & - & 80 & 1 & 60 & 1.3 & Creatinine & $34 \mu \mathrm{mol} / \mathrm{l}$ \\
\hline 12 & F & 10.5 & 200 & - & 80 & 9 & 200 & 1 & ESRF & \\
\hline 13 & $\vec{M}$ & 8.5 & 470 & ++ & 100 & 2 & 180 & 1 & ESRF & \\
\hline 14 & $\mathbf{M}$ & 6.7 & 230 & - & 85 & 2 & 85 & 9 & Creatinine & $86 \mu \mathrm{mol} / 1$ \\
\hline \multicolumn{11}{|c|}{ Systemic lupus erythematosus } \\
\hline 1 & $\mathrm{~F}$ & 15.9 & 322 & ++ & 50 & 1 & 67 & Lost & - & \\
\hline 2 & $F$ & 6.5 & 790 & ++ & DEP & 1 & 67 & 3 & Creatinine & $64 \mu \mathrm{mol} / 1$ \\
\hline 3 & $\bar{M}$ & 6.9 & 420 & ++ & PN & 1 & 68 & 1.6 & Creatinine & $43 \mu \mathrm{mol} / 1$ \\
\hline 4 & $\mathbf{F}$ & 10.0 & 140 & - & 40 & 20 & 52 & 4 & Creatinine & $57 \mu \mathrm{mol} / 1$ \\
\hline \multicolumn{11}{|c|}{ Polyarteritis nodosa } \\
\hline 1 & $\mathbf{M}$ & 3.6 & 400 & ++ & IL & 96 & 400 & 1 & ESRF & \\
\hline 2 & $\mathrm{~F}$ & 13.0 & 640 & ++ & 100 & 1 & 260 & 1 & Creatinine & $280 \mu \mathrm{mol} / 1$ \\
\hline \multicolumn{11}{|c|}{ Wegener's granulomatosis } \\
\hline 1 & $\mathrm{~F}$ & 11.9 & 603 & - & 1010 & 0 & 100 & 2 & Creatinine & $120 \mu \mathrm{mol} / 1$ \\
\hline
\end{tabular}

$\mathrm{DEP}=$ diffuse extracapillary proliferation; $\mathrm{IL}=$ ischaemic lesions; $\mathrm{PN}=$ proliferation and necrosis.

thematosis, six polyarteritis nodosa, and one Wegener's granulomatosis).

PLASMA EXCHANGE PROCEDURE

Two different methods of plasma exchange were used. Children weighing below $15 \mathrm{~kg}$ underwent plasma filtration with a Gambro plasma filter and an AK 10 blood monitor (Gambro). Children above $15 \mathrm{~kg}$ underwent centrifugal plasma exchange with a Cobe Spectra Apheresis system. The volume exchanged was twice the child's estimated plasma volume. Albumin and fresh frozen plasma were used as replacement fluids. Using the median value, one course of plasma exchange was performed (range 1-6), eight exchanges were completed (range 2-28) and three litres of plasma were exchanged for each session of treatment (range 1-4 litres/daily). Few side effects were observed: there was overload in two patients that required haemofiltration, cardiac arrest probably due to hypocalcaemia in one patient who was resuscitated, and anaphyeblaxis due to plasma in one case in which treatment was subsequently discontinued.

DEFINITION OF IMPROVEMENT (RETROSPECTIVELY EVALUATED)

Improvement or lack of improvement in patients was defined as follows:

Groups A and B: recovery of renal function independent of dialysis, with a fall in serum creatinine of at least $30 \%$ from the initial value. Suppression of disease flare-up was also considered in patients with vasculitis.

Group C: normalisation of ESR when it was high in systemic lupus erythematosus, polyarteritis nodosa, and Wegener's granulomatosis; regression of clinical symptoms and no new manifestations of the disease.

Definition of lack of improvement: no change in initial state in terms of renal function and/or general condition.

Table 4 Vasculitis without renal disease $(n=15)$

\begin{tabular}{|c|c|c|c|c|c|c|c|}
\hline \multirow[b]{2}{*}{ Patient No } & \multirow[b]{2}{*}{$\operatorname{Sex}$} & \multirow[b]{2}{*}{ Age at onset (years) } & \multirow[b]{2}{*}{$\begin{array}{l}\text { Before plasma } \\
\text { exchange }\end{array}$} & \multirow[b]{2}{*}{$\begin{array}{l}\text { Time onset - plasma } \\
\text { exchange (months) }\end{array}$} & \multirow[b]{2}{*}{$\begin{array}{l}2 \text { Months after } \\
\text { plasma exchange }\end{array}$} & \multicolumn{2}{|l|}{ Last follow up } \\
\hline & & & & & & Time (years) & Outcome \\
\hline \multicolumn{8}{|c|}{ Henoch-Schönlein purpura } \\
\hline 1 & $\mathbf{F}$ & 10.0 & Seizures & 1 & Improvement & 6 & Recovery \\
\hline 2 & $\mathbf{F}$ & 7.0 & Coma & 1 & Improvement & 5 & Recovery \\
\hline 3 & $\mathbf{F}$ & 8.1 & Seizures & 0 & Improvement & 3 & Recovery \\
\hline \multicolumn{8}{|c|}{ Systemic lupus erythematosus } \\
\hline 1 & $\mathbf{M}$ & 11.0 & Deterioration & 1 & No improvement & & Death \\
\hline 2 & $\mathbf{F}$ & 12.2 & Low platelets & 5 & No improvement & 1.4 & No improvement \\
\hline \multicolumn{8}{|c|}{ Polyarteritis nodosa } \\
\hline 1 & $\mathbf{M}$ & 10.0 & Seizures & 33 & Improvement & 6 & Remission \\
\hline 2 & $\mathbf{F}$ & 2.2 & Deterioration & 10 & Improvement & & Death \\
\hline 3 & $\mathbf{M}$ & 5.7 & Deterioration & 84 & No improvement & 2 & Remission \\
\hline 4 & $\mathbf{F}$ & 1.4 & Seizures, coma & 4 & No improvement & & Death \\
\hline 5 & $\mathbf{M}$ & 12.0 & Deterioration & 1 & No improvement & 5 & Remission \\
\hline 6 & $\mathbf{F}$ & 11.3 & Deterioration & 9 & Improvement & 4 & Remission \\
\hline 7 & $\mathbf{F}$ & 4.0 & Deterioration & 5 & No improvement & 3 & Remission \\
\hline 8 & $\mathbf{M}$ & 14.0 & Deterioration & 2 & Improvement & 2 & Remission \\
\hline 9 & $\mathbf{M}$ & 11.0 & Deterioration & 15 & Improvement & & Death \\
\hline \multicolumn{8}{|c|}{ Wegener's granulomatosis } \\
\hline 1 & $\mathbf{F}$ & 6 & Deterioration & 24 & No improvement & 5 & Remission \\
\hline
\end{tabular}


OUTCOME

Clinical and laboratory assessment was considered two months after the exchanges (short term outcome) and at the longest follow up available (long term outcome).

\section{STATISTICS}

The $T$ test for paired data was used to evaluate any significant difference in serum creatinine before and after plasma exchange. The $\chi^{2}$ test was used to evaluate any significant difference in the proportion of patients who improved, depending on when they started plasma exchange. The Mann-Whitney test was used to assess any significant difference in the time of onset-plasma exchange between patients who improved and patients who did not improve.

\section{Results}

In group A (12 cases) seven patients (58\%) showed improvement or normalisation of serum creatinine at two months; all of them stopped dialysis. The analysis of mean serum creatinine showed a significant decrease after plasma exchange (mean value before was 584 $\mu \mathrm{mol} / 1$ v $79 \mu \mathrm{mol} / 1$ after, $\mathrm{p}=0.001)$. Five patients did not benefit from plasma exchange, including the case that remained in end stage renal failure (ESRF) despite a fall in serum creatinine of $49 \%$ after plasma exchange (table 2 , number 4). The mean time of onset-plasma exchange did not differ significantly between patients that recovered and those that did not. The mean (SD) of the longest follow up was 3.0 (2.5) years (range $1-8$ ). Six patients $(50 \%)$ maintained a normal creatinine concentration. Five went on to ESRF and one died of septicaemia.

In group $B$ (21 cases) all 15 patients who had a mean time of onset-plasma exchange of one month and $3 / 6(50 \%)$ treated after a mean time of 31 months, showed improved or normalised renal function at two months $(p=0.02)$. All of them stopped dialysis. Comparison of the mean serum creatinine before and after plasma exchange in the 15 cases showed a significant difference: $434 \mu \mathrm{mol} / \mathrm{l} v$ $96 \mu \mathrm{mol} / 1, \mathrm{p}=0.0001$. The mean (SD) of the longest follow up was 3.0 (2.3) years (range 1-9). One case was lost to follow up; $13 / 14$ cases $(93 \%)$ maintained normal or stable renal function compared with $1 / 6(17 \%)(p=0.004)$; six patients went on to ESRF. In group $B$ it was also evident that patients promptly started on plasma exchange (within one month) had a better renal outcome $(p=0.0001)$. No patients manifested any symptoms of vasculitis after treatment with plasma exchange.

In group $C$ ( 15 cases) $4 / 9$ patients $(44 \%)$, in which the mean time of onset-plasma exchange was 2.26 months, showed clinical improvement at two months compared with $4 / 6(67 \%)$ cases treated later (this was not significant). The mean (SD) of the longest follow up was 3.8 (1.6) years (range 1.4-6.0). Ten patients $(67 \%)$ had a favourable outcome $(6 / 9(67 \%)$ and 4/6 (67\%)); five patients with polyarteritis nodosa had a normal ESR, whereas one with polyarteritis nodosa and the patient with Wegener's granulomatosis continued to have a high ESR, but no symptoms of flare-up. In one patient with systemic lupus erythematosus thrombocytopenia did not improve; four patients died: three of septicaemia and one of cerebral disease due to polyarteritis nodosa. The time of onset-plasma exchange did not influence the outcome in this group of patients, even though six cases started plasma exchange significantly later than the other nine cases $(\mathrm{p}=0.002)$.

\section{Discussion}

Since the first description of benefit in the treatment of Goodpasture's syndrome, plasma exchange has been used in many cases of vasculitis and systemic lupus erythematosus with or without renal involvement and in IRPGN. ${ }^{2-16}$ Over the last 10 years, a number of studies performed on adult patients have attempted to demonstrate the value of plasma exchange, but the majority of the results were controversial. Guillevin et al reported a trial that failed to show additional benefit in patients with polyarteritis nodosa and ChurgStrauss syndrome treated with steroids plus plasma exchange, compared with those treated with steroids alone. ${ }^{5}$ In another trial, the same authors observed that the association of cyclophosphamide with steroids and plasma exchange reduced the incidence of relapses in the same type of patients. ${ }^{6}$ Leaker $e t$ al found an improvement in 10/12 patients with systemic lupus erythematosus with severe nephropathy who were treated with immunosuppressive medication plus plasma exchange. ${ }^{7}$ However, a recent trial performed by Lewis et al did not show any improvement in systemic lupus erythematosus with severe nephritis treated with immunosuppressive medication plus plasma exchange, compared with immunosuppressive medication alone. ${ }^{8}$ In two trials enrolling secondary and/or idiopathic RPGN, Glockner et $a l^{9}$ and Cole et $a l^{10}$ did not find any significant difference in outcome when patients were also treated with plasma exchange. By contrast, in another trial enrolling the same sort of patients, Pusey et al observed a benefit in using plasma exchange only in patients requiring dialysis at the onset of the disease. ${ }^{11}$ Few data are available on children. Dillon et $a l^{12}$ Tizard and Dillon, ${ }^{14}$ and Jardim et al ${ }^{15}$ reviewed a series of children, some of whom are included in the present study. Although some improvement was observed, the results varied. Jordan et al reported on six cases with systemic lupus erythematosus and severe nephritis unresponsive to immunosuppressive medication in which plasma exchange caused an improvement in outcome. ${ }^{16}$ To date, there are no reports of patients with HenochSchönlein purpura treated with plasma exchange, although there are a few anecdotal examples in the literature. ${ }^{121415}$ However, some reports suggest that immunosuppressive medication alone is not always sufficient in cases with severe renal involvement. ${ }^{21} 22$

Although collected retrospectively, the cases presented here represent the largest paediatric series of IRPGN, renal and non-renal vasculitis 
treated with plasma exchange from a single centre ever reported. Despite all children being treated with immunosuppressive medication, a severe clinical picture, renal involvement at onset, impairment of renal function, and/or the occurrence of flare-ups in vasculitis were indications for treatment with plasma exchange. The superiority of plasma exchange over immunosuppressive medication was not demonstrated, but some of the data suggest a possible benefit from the addition of this treatment to immunosuppressive medication. Outcome improved if plasma exchange was started promptly, especially in terms of renal involvement. Fifteen of 21 cases with RPGN and vasculitis started plasma exchange within one month after disease onset. Renal function improved significantly in all of them when evaluated at two months; $93 \%$ still maintained good renal function at the longest available follow up. The time of onset-plasma exchange was not significantly different in patients with IRPGN who improved and those who did not. However, considering that it was relatively short in all of them (mean one month) and that the reduction of serum creatinine after plasma exchange was significant, we can conclude that plasma exchange was effective also in this group of patients. Furthermore, no patients with renal and non-renal vasculitis showed any systemic features after plasma exchange and none died of vasculitis. Only four patients showed side effects due to plasma exchange, and among the four patients who died of septicaemia, three manifested this condition before plasma exchange and one two months after. In this context, a trial showed that plasma exchange does not increase the risk of infection in immunosuppressed adults with severe systemic lupus erythematosus nephritis. ${ }^{23}$ We therefore believe that plasma exchange can be considered a safe treatment and that the risk of infection should not be a contraindication to starting it in children.

\section{CONCLUSION}

Our retrospective data suggest that, if started early after disease onset, plasma exchange can be effective in improving renal outcome in children with IRPGN and vasculitis with RPGN. Good response can also be obtained in terms of other systemic features and when clinical deterioration due to vasculitis is present. However, this treatment should be limited to those cases with severe renal involvement and clinical picture. In such patients, our data show that plasma exchange is a relatively safe procedure when performed by experienced staff. After a retrospective study such as ours, it is often suggested that a future trial might help to resolve the question of the value of plasma exchange in treating childhood IRPGN and vascular diseases. We think that a randomised controlled trial might clarify the value of plasma exchange in treating these disorders, but it would be difficult to recruit a sufficient number of patients, as these diseases are very rare in children. Furthermore, if only severe cases were to be treated, the criteria for randomising them would be very difficult to define.

We wish to thank the senior nursing staff of the Renal Unit of the Hospital for Sick Children for their expert help and support in undertaking the many plasma exchange procedures that have been retrospectively reviewed in this paper.

1 Lockwood CM, Boulton-Jones JM, Lowenthal RM, Simpson IJ, Peters DK, Wilson CB. Recovery from Goodpasture's syndrome after immmunosuppressive treatment and plasmapheresis. BMF 1975; ii: 252-4

2 Lockwood CM, Pinching AJ, Sweny P, Rees AJ, Pussell B, Uff $J$. Plasma-exchange and immunosuppression in the treatment of fulminating immune-complex crescentic nephritis. Lancet 1977; i: 63-7.

3 Verrier-Jones J, Cumming RH, Bacon PA, et al. Evidence for a therapeutic effect of plasmapheresis in patients with systemic lupus erythematosus. $Q \mathcal{F}$ Med $1979 ; 192: 555-76$.

4 Couser WG. Rapidly progressive glomerulonephritis: classification, pathogenetic mechanisms and therapy. $A m \mathcal{F}$ Kidney Dis 1988; 6: 449-64.

5 Guillevin L, Fain O, Lhote F, et al. Lack of superiority of steroids plus plasma exchange to steroids alone in the steroids plus plasma exchange to steroids alone in the
treatment of polyarteritis nodosa and Churg-Strauss treatment of polyarteritis nodosa and Churg-Strauss
syndrome. A prospective, randomized trial in 78 patients. syndrome. A prospective, randomized
Arthritis Rheum 1992; 35: 208-15.

6 Guillevin L, Jarrousse B, Lok C, et al. Long-term follow-up after treatment of polyarteritis nodosa and Churg-Strauss angiitis with comparison of steroids, plasma-exchange and cyclophosphamide to steroids and plasma exchange. A prospective randomized trial of 71 patients. $\mathcal{F}$ Rheumato 1991; 18: 567-74.

7 Leaker BR, Becker GJ, Dowling JP, Kincaid-Smith PS. Rapid improvement in severe lupus glomerular lesions following intensive plasma exchange associated with immunosuppression. Clin Nephrol 1986; 25: 236-44.

8 Lewis EJ, Hunsicker LG, Shu-Ping Lan, Rohde RD, Lachin JM, for the Lupus Nephritis Collaborative Study Group. A JM, for the Lupus Nephritis Collaborative Study Group. A controlled trial of plasmapheresis therapy in
nephritis. N Engl f Med 1992; 326: 1373-9.

9 Glockner WM, Sieberth HG, Wichmann HE. Plasma exchange and immunosuppression in rapidly progressive glomerulonephritis: a controlled, multi-center study. Clin Nephrol 1988; 29: 1-8.

10 Cole E, Cattran D, Magil A, et al. A prospective randomized trial of plasma exchange as additive therapy in idiopathic crescentic glomerulonephritis. Am $\mathcal{F}$ Kidney Dis 1992; 3: 261-9.

11 Pusey CD, Rees AJ, Evans DJ, Peters DK, Lockwood CM. Plasma exchange in focal necrotizing glomerulonephritis without anti-GBM antibodies. Kidney Int 1991; 40: 757-63.

12 Dillon MJ, Barratt TM, Sabbagh PA, et al. Plasma-exchange in children: results in vasculitis and haemolytic uraemic syndrome. In: Murakami K, Kitegawa T, Yabuta K, Sakai $\mathrm{T}$, eds. Recent advances in pediatric nephrology. Amsterdam: T, eds. Recent advances in pediatric

13 Walters MDS, Savage COS, Dillon MJ, Lockwood CM, Barratt TM. Antineutrophil cytoplasm antibody in cresBarratt TM. Antineutrophil cytoplasm antibody in cres-

14 Tizard EJ, Dillon MJ. Plasmapheresis in childhood. Care of the Critically III 1991; 7: 51-5.

15 Jardim HMPF, Leake J, Risdon RA, Barratt TM, Dillon MJ. Crescentic glomerulonephritis in children. Pediatr Nephrol 1992; 6: 231-5.

16 Jordan SC, Ho W, Ettenger R, Salusky IB, Fine RN. Plasma exchange improves the glomerulonephritis of systemic lupus erythematosus in selected pediatric patients. Pediat Nephrol 1987; 1: 276-80.

17 Tan EM, Cohen AS, Fries JF, et al. The 1982 revised criteria for the classification of systemic lupus erythematosus. Arthritis Rheum 1982; 25: 1271-7.

18 Lighfoot RW, Michel BA, Bloch DA, et al. The American College of Rheumatology 1990 criteria for the classification of polyarteritis nodosa. Arthritis Rheum 1990; 33: 1088-93. 19 Leavitt RY, Fauci AS, Bloch DA, et al. The American Leavitt RY, Fauci AS, Bloch DA, et al. The American
College of Rheumatology 1990 criteria for the classification of Wegener's granulomatosis. Arthritis Rheum 1990; 33: of Wegen

20 Mills JA, Michel BA, Bloch DA, et al. The American College of Rheumatology 1990 criteria for the classification of Henoch-Schönlein purpura. Arthritis Rheum 1990; 33:1114-21.

21 Counahan R, Winterborn MH, White RHR, et al. Prognosis of Henoch-Schönlein nephritis in children. BMF 1977; 2: 11-4.

22 Niaudet $P$, Levy $M$. Glomerulonephrites a croissants diffus. In: Royer P, Habib R, Mathieu H, Broyer M, eds. Nephrologie pediatrique. Flammarion, 1983: 381-94

23 Pohl MA, Lan SP, Berl T, and the Lupus Nephritis Collaborative Study Group. Plasmapheresis does not increase the risk for infection in immunosuppressed patients with severe lupus nephritis. Ann Intern Med 1991; 114: 924-9. 